\title{
Correction to: Unusual Severe Seborrheic Dermatitis in Two Siblings with Autosomal Recessive Chronic Granulomatous Disease
}

\author{
Nuria Bengala Zurro ${ }^{1}$ • Edgar Borges de Oliveira Junior ${ }^{1}$ - Tábata Takahashi França ${ }^{1}$. Vera Maria Dantas ${ }^{2}$.
} Jose Antonio Tavares de Albuquerque ${ }^{1} \cdot$ Antonio Condino-Neto ${ }^{1}$ (B)

Published online: 2 November 2019

(C) Springer Science+Business Media, LLC, part of Springer Nature 2019

Correction to: Journal of Clinical Immunology (2019) https://doi.org/10.1007/s10875-019-00681-w

The original version of this article contained an error in Fig. 1. The incomplete heredogram mistakenly appeared in panel $\mathbf{d}$.

The original article has been corrected.

The online version of the original article can be found at https://oi.org/ 10.1007/s10875-019-00681-w

Antonio Condino-Neto

antoniocondino@gmail.com; condino@usp.br

1 Department of Immunology, Institute of Biomedical Sciences, University of São Paulo, São Paulo SP Brazil

2 Department of Pediatrics, Federal University of Rio Grande do Norte, Natal RN Brazil 